\title{
CHALLENGES DURING THE PANDEMIC: USE OF E-LEARNING IN MATHEMATICS LEARNING IN HIGHER EDUCATION
}

\author{
Muhammad Irfan, Betty Kusumaningrum, Yuyun Yulia, Sri Adi Widodo* \\ Universitas Sarjanawiyata Tamansiswa, Yogyakarta, Indonesia
}

\begin{tabular}{l} 
Article Info \\
\hline Article history: \\
Received Jul 19, 2020 \\
Revised Aug 20, 2020 \\
Accepted Aug 26, 2020 \\
\hline
\end{tabular}

\section{Keywords:}

Pandemic,

Covid-19,

Online Learning,

Mathematics Learning

\begin{abstract}
On March 16, 2020, many universities in Indonesia began implementing online-based learning to replace lectures in the classroom. This is done as a way to reduce the transmission of the Covid-19 outbreak in Indonesia. There is an opinion that with the implementation of online learning, especially in mathematics education study programs, there are many obstacles when learning takes place. This study aims to determine the obstacles that arise after the implementation of online learning in mathematics learning in Higher Education. This research is a qualitative case study, assisted by an online survey. The researcher collected data through an online survey consisting of 27 questions. The survey is aimed at lecturers who teach in Mathematics Education study programs in Indonesia. The survey contains structured questions and leads to three parts, namely; basic skills challenges, teaching and learning challenges, and university challenges. The 27 questions contained questions about the ability of platform mastery to support online learning owned by each lecturer. The research involved 26 lecturers from universities in Sumatra, Java, Kalimantan, and Sulawesi. The results of this study reveal that all lecturers affected by the pandemic use a Learning Management System (LMS) based website as a means of online learning. The learning management system-based platform is the most widely used (google class and Edmodo) while video conferencing is the second choice (Zoom and Skype). What is interesting is that the LMS available on campus is less attractive to lecturers. However, there are obstacles faced such as the limitations of writing mathematical symbols and the limited basic capabilities of the learning management system and multimedia software to support online learning.
\end{abstract}

Copyright $(2020$ IKIP Siliwangi. All rights reserved.

\section{Corresponding Author:}

Sri Adi Widodo,

Department of Mathematics Education,

Universitas Sarjanawiyata Tamansiswa

Jl. Batikan UH III/1043, Umbulharjo, Yogyakarta 55165, Indonesia

Email: sriadi@ustjogja.ac.id

\section{How to Cite:}

Irfan, M., Kusumaningrum, B., Yulia, Y., \& Widodo, S. A. (2020). Challenges during the pandemic: Use of e-learning in mathematics learning in higher education. Infinity, 9(2), 147-158.

\section{INTRODUCTION}

Indonesia confirmed the first case of Covid-19 on March 2, 2020 (Setiawan, 2020; Setiawan \& Ilmiyah, 2020; Tosepu et al., 2020). Two weeks ago, many universities in Indonesia issued a learning policy at home and implemented online learning. Until May 16, 2020 , the number of confirmed cases was 16,496 positive (Kemenkes RI, 2020). With the 
implementation of the learning policy at home by tertiary institutions, many lecturers began to use the learning management system (LMS) platform as well as video conferences that could assist in mathematics learning activities (Gunawan et al., 2020; Sulisworo et al., 2020). In Indonesia, the most widely used LMS platforms include: google classroom, Edmodo, elearning portals for each tertiary institution, etc. As for video conferences, you can use Zoom, Webex, Google Meet, Microsoft Teams, etc.

Online learning in a pandemic is an alternative solution (Basilaia \& Kvavadze, 2020; Bauerlein, 2008; Laprairie \& Hinson, 2006; Taha et al., 2020). The use of online learning is indeed practical because it can be used anywhere and anytime (Bourne et al., 2005; Means, 2010; Nakamura et al., 2018; Özyurt et al., 2013). However, do not close your eyes that the implementation of online learning raises its problems (Hung \& Chou, 2015; Smart \& Cappel, 2006; Van Bruggen, 2005). Therefore, higher education that has limited or no experience of e-learning or e-learning resources experiences difficulties, especially, when lecturers lack knowledge of how to use online applications (Kim \& Bonk, 2006; Zaharah \& Kirilova, 2020).

Implementation of online learning in higher education does have advantages and disadvantages. The advantages of online learning are that it is flexible and can be widely used, while the drawback is that it is very potential to do plagiarism practices, internet signal strength, and devices that support (Arkorful \& Abaidoo, 2015; Irfan, 2015). Since COVID19 Pandemic occurred in Indonesia, research on COVID-19 began to be carried out. In the field of mathematical modeling, many experts predict when the pandemic reaches its peak when it ends, and the transmission model of the spread of viruses (Kim et al., 2020; Ndaïrou et al., 2020; Nuraini et al., 2020; Peirlinck et al., 2020; Rahimi \& Abadi, 2020; Resmawan \& Yahya, 2020; Soewono, 2020; Tang et al., 2020). Whereas in learning mathematics in schools, research on obstacles in the use of e-learning that occurred in schools (Mailizar et al., 2020; Mulenga \& Marbán, 2020).

Much research on barriers caused by the application of online learning in nonpandemic situations (Ali \& Magalhaes, 2008; Beetham \& Sharpe, 2007; Eady \& Lockyer, 2013; Karasavvidis, 2010). While research on barriers to the use of online learning during the pandemic is still not widely done. Mailizar et al. (2020) initiated research on barriers to the use of e-learning in Indonesia, but the participants involved were mathematics teachers. This research was conducted in Indonesia at the time of the Pandemic period and focused to find out the obstacles that arise after the implementation of online learning in mathematics learning in Higher Education. Most of the studies conducted did not focus on learning mathematics in tertiary institutions (Ali et al., 2018; Donnelly \& McSweeney, 2008; Kabilan $\&$ Khan, 2012). This poses many challenges but at the same time highlights the importance of investigating e-learning barriers for mathematics education lecturers during a pandemic. This research was conducted in Indonesia which focuses on the challenges and obstacles faced by lecturers who teach in Mathematics Education study programs during a pandemic. Therefore, to see the challenges and obstacles faced by lecturers who teach in Mathematics Education study programs during the pandemic, researchers feel the need to focus on three aspects, namely basic skills challenges, teaching and learning challenges, and university challenges.

The findings from this study will help advance our understanding of the obstacles to e-learning integration amid the COVID-19 pandemic in the context of developing countries at the tertiary level. Therefore, this study adds valuable insights to the e-learning literature and provides important suggestions for improving e-learning practices. To achieve this goal, this study aspires to answer questions (1) What are the challenges faced by lecturers in implementing e-learning during a pandemic? and (2) what is the basic ability possessed by lecturers to support e-learning? 


\section{METHOD}

\subsection{Research Design}

This research is qualitative research with a type of case study. The cases studied are the challenges faced by lecturers in implementing e-learning during a pandemic and what basic abilities lecturers have to support e-learning. In line with (Creswell, 2012a; 2012b), qualitative research is exploratory in nature, which helps researchers to find out more about the challenges faced by mathematics education lecturers during the Pandemic in teaching and learning activities. This research cannot help in making a decision or coming to a conclusion (generalization). However, this research can help understand how mathematics education lecturers in Indonesia experience obstacles in undergoing teaching and learning activities using e-learning during the Pandemic.

\subsection{Participants}

Random sampling was used in this study. This is because the researcher cannot control who and from the institution, the respondent is from. Researchers only limit and ensure that the subjects used in this study are lecturers in mathematics education in Indonesia. Researchers do not limit whether they are from State Universities or not, respondent's age, length of work, and gender. This is different from research (Mailizar et al., 2020) whose participants are mathematics teachers and are categorized based on length of work, gender, and also certification. The research involved 26 lecturers from universities in Sumatra, Java, Kalimantan, and Sulawesi.

\subsection{Research Instruments}

The instrument in this study was made by researchers and was discussed in a group discussion forum (FGD-Online). For this reason, researchers collected data through an online survey consisting of 27 questions. The survey is aimed at lecturers who teach in Mathematics Education study programs in Indonesia. Of the 27 questions consisted: 3 question contains participant's profile such as name, email address and place of study of the participant; 3 questions contained information about people who were positively affected by Covid-19 in the college's; 3 questions about the college's response and each lecturer in responding to Pandemics in learning; and the remaining questions were about the ability to master the platform that supports learning online owned by each lecturer consisting of basic skills challenges, teaching and learning challenges, and university challenges.

\subsection{Data Collection and Analysis}

Data was collected using an online survey. Online surveys are used for reasons of the flexibility of compatibility with lecturers' online work during a pandemic. Also, online surveys are easily managed and accessed using various devices (Fraenkel et al., 2012). The survey was distributed after passing the evaluation process from the results of the FGD Online which involved 4 e-learning experts from 3 universities in Indonesia. Furthermore, online surveys are disseminated through WhatsApp groups, e-mails, and also Facebook in March 2020. Google form was chosen by the researcher to make an online survey because of its ease of use. After the respondent fills in the survey, the respondent will get a recapitulation of the results and can then be confirmed by the researcher. The questionnaire is open for three weeks. The data obtained are then grouped based on basic skills challenges, 
teaching and learning challenges, and university challenges. The data obtained is then interpreted and described by researchers.

\section{RESULTS AND DISCUSSION}

\subsection{Results}

The results obtained from filling out an online survey show that learning management system-based platforms are the most used (google classroom and Edmodo) while video conferencing is the second choice (Zoom and Skype) (see Figure 1). The Webex platform and Google meeting no one uses it on the research subjects. But learning mathematics using conferencing, subjects preferred to use zoom and skype.

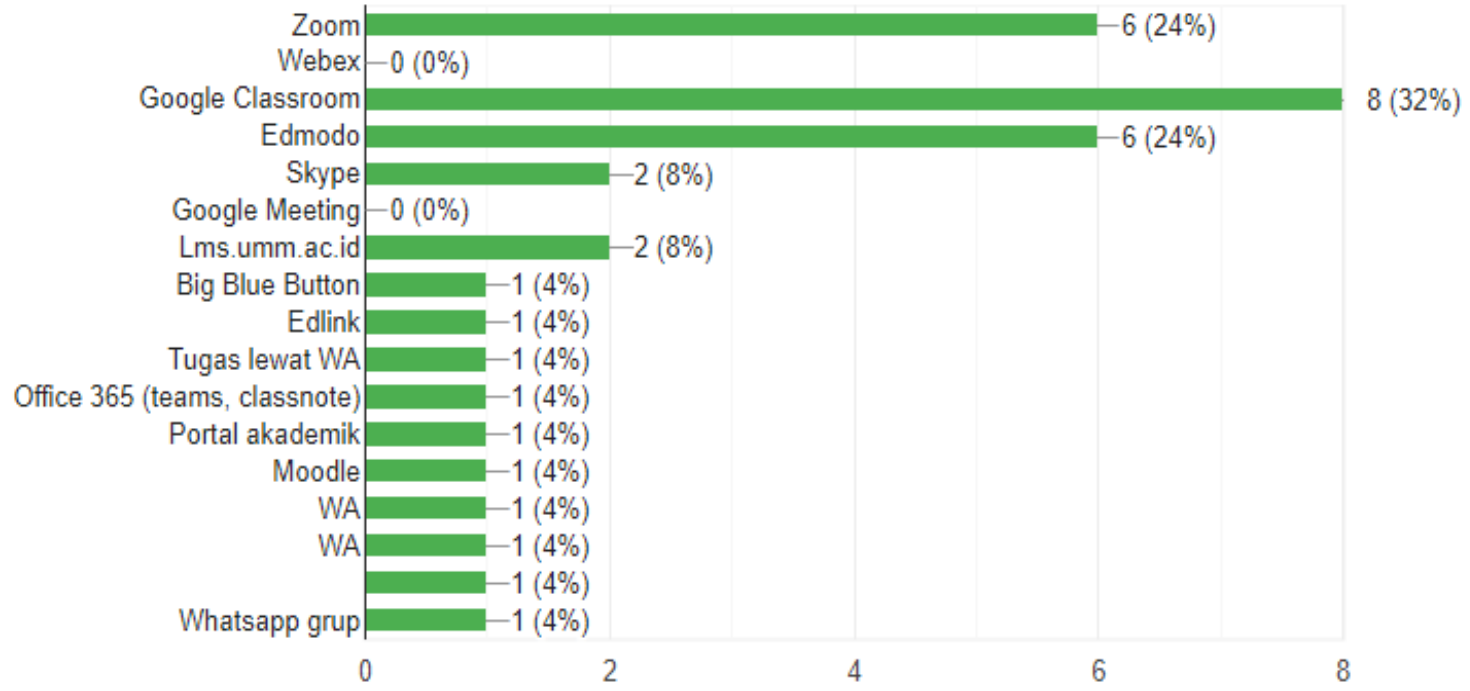

Figure 1. The platform that is often used in e-learning

The results of a survey of respondents used as participants in this study found that in the basic skills challenges section, students generally could use the online learning platform used during the pandemic COVID-19 (see Table 1).

Table 1. The Survey Results of Respondents in Basic Skills Challenges

\begin{tabular}{clccc}
\hline \multirow{2}{*}{ No. } & \multicolumn{1}{c}{ Question } & \multicolumn{3}{c}{ Response (\%) } \\
\cline { 3 - 5 } & \multicolumn{1}{c}{ Yes } & Maybe & No \\
\hline 1. & Have you ever used the application before? & 61.5 & 0 & 38.5 \\
2. $\quad \begin{array}{l}\text { Are you good at Presentation Applications (such } \\
\text { as Microsoft PowerPoint, OpenOffice Impress)? }\end{array}$ & 88.5 & 0 & 11.5 \\
3. $\quad \begin{array}{l}\text { Are you familiar with Spreadsheet Applications } \\
\text { (such as Microsoft Excel, OpenOffice Calc)? }\end{array}$ & 80.8 & 3.8 & 15.4 \\
4. $\begin{array}{l}\text { Do you master Digital Image Recording } \\
\text { Applications (such as: with a Digital Camera } \\
\text { and Scanner)? }\end{array}$ & 73.1 & 7.7 & 19.2 \\
5o you master Multimedia Compilation & 23.1 & 23.1 & 53.8 \\
\hline
\end{tabular}




\begin{tabular}{clccc}
\hline \multirow{2}{*}{ No. } & \multicolumn{1}{c}{ Question } & \multicolumn{3}{c}{ Response (\%) } \\
\cline { 3 - 5 } & \multicolumn{1}{c}{ Yes } & Maybe & No \\
\hline 6. & $\begin{array}{l}\text { Do you master Mind / Concept Mapping } \\
\text { Applications (such as Inspiration, MindMapple, }\end{array}$ & 15.4 & 11.5 & 73.1 \\
$\quad \begin{array}{l}\text { MindJet)? } \\
\text { Do you master Digital Video Applications (such } \\
\text { as Camtasia, Adobe Premiere, MovieMaker, }\end{array}$ & 34.6 & 15.4 & 50 \\
$\quad \begin{array}{l}\text { iMovie)? } \\
\text { Do you master Web Design Applications (such } \\
\text { as Adobe Dreamweaver, Frontpage) }\end{array}$ & 7.7 & 11.5 & 80.8 \\
9. $\begin{array}{l}\text { Do you master Learning Management Systems } \\
\text { (such as Moodle, Edmodo, KhanAcademy)? }\end{array}$ & 38.5 & 15.4 & 46.2 \\
10. $\begin{array}{l}\text { Do you master applications for online meetings } \\
\text { (such as Zoom, Webex, google meeting)? }\end{array}$ & 57.7 & 3.8 & 38.5 \\
11. $\begin{array}{l}\text { Do you feel comfortable using digital } \\
\text { technology? }\end{array}$ & 88.5 & 3.8 & 7.7 \\
\hline
\end{tabular}

Table 1 show that the respondents master Presentation Applications (such as Microsoft PowerPoint, OpenOffice Impress) and also image managers (questions 1-4). However, respondents have weaknesses in making animation and the ability for objectoriented programming (adobe flash and web design) and video editing (questions 5-9). Respondents find it easier to use a ready-to-use and familiar LMS such as Edmodo or google classroom. Also, video conferencing is still the main choice when teaching.

The results of respondents surveys that were used as participants in this study found that in the teaching and learning challenges section, among them most of the students had no training to use online learning platforms. but in general, students are open to the existence of new digital technology, so they always learn independently and find out about digital technology. Especially in a Covid-19 pandemic condition like this, students are required to learn independently including in learning new information technology (see Table 2).

Table 2. The Survey Results of Respondents in Teaching and learning challenges

\begin{tabular}{clccc}
\hline \multirow{2}{*}{ No. } & \multicolumn{1}{c}{ Question } & \multicolumn{3}{c}{ Response (\%) } \\
\cline { 3 - 5 } & \multicolumn{1}{c}{ Yes } & Maybe & No \\
\hline 12. & $\begin{array}{l}\text { Are there courses that cannot apply for your } \\
\text { study program online learning? }\end{array}$ & 18.2 & 9.1 & 72.7 \\
13. & $\begin{array}{l}\text { Do you always learn new digital technology? } \\
\text { 14. }\end{array}$ & 61.5 & 34.6 & 3.8 \\
& $\begin{array}{l}\text { Do you always find out about new digital } \\
\text { technology? }\end{array}$ & 61.5 & 34.6 & 3.8 \\
15. & $\begin{array}{l}\text { Can you combine course content with } \\
\text { technology and appropriate teaching } \\
\text { approaches? }\end{array}$ & 65.4 & 34.6 & 0 \\
16. & $\begin{array}{l}\text { Do you understand and can conduct } \\
\text { performance assessments (for example student } \\
\text { performance)? }\end{array}$ & 88.5 & 11.5 & 0 \\
\hline
\end{tabular}


Table 2 show that the problems faced by lecturers during online learning are limitations in delivering material, especially pure mathematics. This is reasonable because to teach the material, special software (eg MathType) is required. In addition, the computer programming course also encountered problems, because lecturers found it difficult to check the obstacles faced by students, and students found it difficult to convey their problems. This is because programming courses are related to syntax, computer specifications, software, and algorithms. Of course, this becomes something complex.

The results of a student survey that were used as participants in this study found that in the university challenges section. The most interesting thing is found as many as $73.1 \%$ of respondents stated that tertiary institutions have e-learning websites but only $34.6 \%$ use them (see Table 3).

Table 3. The Survey Results of Respondents in university challenges

\begin{tabular}{clccc}
\hline \multirow{2}{*}{ No. } & \multicolumn{1}{c}{ Question } & \multicolumn{3}{c}{ Response (\%) } \\
\cline { 3 - 5 } & \multicolumn{1}{c}{ Yes } & Maybe & No \\
\hline 17. & $\begin{array}{l}\text { Does the university where you work have e- } \\
\text { learning facilities? }\end{array}$ & 73.1 & 3.8 & 23.1 \\
18. & Have you used it for learning? & 34.6 & 30.8 & 34.6 \\
\hline
\end{tabular}

\subsection{Discussion}

In addition to the challenges faced by lecturers, this study also aims to find out whether the basic abilities possessed by lecturers to support the application of e-learning. The findings show two important points of interest. First, this research shows that the obstacles to implementing e-learning in tertiary institutions include: lecturers have mastered the basic skills to support e-learning learning (Al-Rahmi et al., 2015; Ash et al., 2003; Davies et al., 2017; Govindasamy, 2001; Pundak et al., 2010; Trelease, 2015), but precisely the obstacles to the mathematical content (Sözgün et al., 2018; Vrugt \& Oort, 2008). The lecturers find it difficult when they have to teach online on mathematics (Adnan \& Boz, 2015; Kurt, 2017; Lin et al., 2017). Also, many lecturers use learning management systems that are publicly available (eg Edmodo and google classroom) rather than e-learning developed by their tertiary institutions. The findings show that lecturers were ready to use elearning before this pandemic. Therefore, when this pandemic comes, they are not so panicked to do online learning. This contrasts with the results of research (Ali \& Magalhaes, 2008; Assareh \& Bidokht, 2011; Childs et al., 2005) which show that there are many obstacles in the application of e-learning during a pandemic.

This pandemic brings us to an unusual life, including in learning mathematics in college. Surely, the findings of this study cannot be used as a benchmark when learning in normal (non-pandemic) situations. Also, this research focuses on mathematics learning where the implementation of e-learning presents new challenges to lecturers due to difficulties in explaining mathematical concepts online (Frid, 2002; Nakamura et al., 2018).

Second, this research shows that lecturers prefer to use e-learning platforms that are widely available (eg Edmodo and Google Classroom) or use video conferencing (zoom or skype) rather than using e-learning developed by universities. This shows that the lecturers are not satisfied with the features and facilities of the university e-learning. Some suggested by lecturers includes: there is an attendance system that can be recorded properly and can be exported in the form of Excel, the presence of video conferencing features, and an 
assessment system. This suggestion makes great sense because it is indeed a necessity when learning (Albelbisi \& Yusop, 2018; Ali et al., 2018; Donnelly \& McSweeney, 2008).

This study examines the challenges faced by lecturers when implementing e-learning during the pandemic. It is not easy for lecturers who are used to teaching in class and must be replaced by using e-learning. Many obstacles are faced, one of which is the availability of features in the academic portals of each tertiary institution, the limited interaction between lecturers and students, and limitations in writing mathematical symbols. This certainly can be used as further research on the challenges and obstacles faced by students in using elearning, the development of e-learning systems of each tertiary institution, and also the resolution related to mathematical symbols that tend to be difficult if written on several elearning platforms.

\section{CONCLUSION}

During the Covid-19 Pandemic, universities in Indonesia have implemented many online-based learning policies. This is a form of a rapid response from universities in Indonesia to minimize Covid-19 transmission in the campus environment. However, this policy still provides several obstacles that arise from both lecturers and students. In this study, it shows that the challenges faced by lecturers in implementing online learning include: limitations in presenting material, especially when courses have many mathematical equations and programming languages. Besides, the lecturers are not good at video editing or animation using various animation maker software. They are limited to presenting material using PowerPoint and text. Overall, to use online learning, lecturers must at least master presentation software, text processing, assessment, and video conferencing. This study proves that higher education policies by implementing online learning are not accompanied by the ability to use platforms that can support online learning. This research can be used as a reference to explore further the obstacles faced by students when online learning is implemented.

\section{ACKNOWLEDGMENTS}

The authors would like to thank the Institute of Research, Development, and Community Service, Universitas Sarjanawiyata Tamansiswa for providing funding for this research.

\section{REFERENCES}

Adnan, M., \& Boz, B. (2015). Faculty Members' Perspectives on Teaching Mathematics Online: Does Prior Online Learning Experience Count? Turkish Online Journal of Qualitative Inquiry, 6(1), 21-38. https://doi.org/10.17569/tojqi.60223

Al-Rahmi, W. M., Othman, M. S., \& Yusuf, L. M. (2015). The effectiveness of using elearning in Malaysian higher education: A case study universiti Teknologi Malaysia. Mediterranean Journal of Social Sciences, 6(5). https://doi.org/10.5901/mjss.2015.v6n5s

Albelbisi, N. A., \& Yusop, F. D. (2018). Secondary School Students' Use of and Attitudes toward Online Mathematics Homework. Tojet - The Turkish Online Journal of Educational Technology, 17(1), 144-153.

Ali, G. E., \& Magalhaes, R. (2008). Barriers to implementing e-learning: A Kuwaiti case study. International Journal of Training and Development. 
https://doi.org/10.1111/j.1468-2419.2007.00294.x

Ali, S., Uppal, M. A., \& Gulliver, S. R. (2018). A conceptual framework highlighting elearning implementation barriers. In Information Technology and People. https://doi.org/10.1108/ITP-10-2016-0246

Arkorful, V., \& Abaidoo, N. (2015). The role of e-learning, advantages and disadvantages of its adoption in higher education. International Journal of Instructional Technology and Distance Learning, 12(1), 29-42.

Ash, J. S., Stavri, P. Z., \& Kuperman, G. J. (2003). A consensus statement on considerations for a successful CPOE implementation. Journal of the American Medical Informatics Association, 10(3), 229-234. https://doi.org/10.1197/jamia.M1204

Assareh, A., \& Bidokht, M. H. (2011). Barriers to E-teaching and E-learning. Procedia Computer Science. 3, 791-795. https://doi.org/10.1016/j.procs.2010.12.129

Basilaia, G., \& Kvavadze, D. (2020). Transition to Online Education in Schools during a SARS-CoV-2 Coronavirus (COVID-19) Pandemic in Georgia. Pedagogical Research, 5(4), 1-9. https://doi.org/10.29333/pr/7937

Bauerlein, M. (2008). Online literacy is a lesser kind: Slow reading counterbalances Web skimming. The Chronicle of Higher Education, 55(4).

Beetham, H., \& Sharpe, R. (2007). Rethinking pedagogy for a digital age: Designing and delivering e-learning. In Rethinking Pedagogy for a Digital Age: Designing and Delivering E-Learning. https://doi.org/10.4324/9780203961681

Bourne, J., Harris, D., \& Mayadas, F. (2005). Online Engineering Education: Learning Anywhere, Anytime. Journal of Engineering Education, 94(1), 131-146. https://doi.org/10.1002/j.2168-9830.2005.tb00834.x

Childs, S., Blenkinsopp, E., Hall, A., \& Walton, G. (2005). Effective e-learning for health professionals and students--barriers and their solutions. A systematic review of the literature--findings from the HeXL project. In Health information and libraries journal. https://doi.org/10.1111/j.1470-3327.2005.00614.x

Creswell, J. W. (2012a). Educational research: Planning, conducting, and evaluating quantitative and qualitative research. In Educational Research, 4. https://doi.org/10.1017/CBO9781107415324.004

Creswell, J. W. (2012b). Research Design Qualitative,Quantitative, and Mixed Second Edition.

Davies, R., Coole, T., \& Smith, A. (2017). Review of Socio-technical Considerations to Ensure Successful Implementation of Industry 4.0. Procedia Manufacturing, 12881295. https://doi.org/10.1016/j.promfg.2017.07.256

Donnelly, R., \& McSweeney, F. (2008). Applied e-learning and e-teaching in higher education. In Applied E-Learning and E-Teaching in Higher Education. https://doi.org/10.4018/978-1-59904-814-7

Eady, M. J., \& Lockyer, L. (2013). Tools For Learning: Technology and Teaching Strategies. Queensland University of Technology.

Fraenkel, J. R., Wallen, N. E., \& Hyun, H. H. (2012). How to Design and Evaluate Research in Education. McGraw-Hill Companies.

Frid, S. (2002). Engaging primary students in working mathematically within a virtual 
enrichment program. Mathematics Education Research Journal, 14(1), 60-79. https://doi.org/10.1007/BF03217116

Govindasamy, T. (2001). Successful implementation of e-Learning. The Internet and Higher Education, 4(3-4), 287-299. https://doi.org/10.1016/S1096-7516(01)00071-9

Gunawan, G., Suranti, N. M. Y., \& Fathoroni, F. (2020). Variations of Models and Learning Platforms for Prospective Teachers During the COVID-19 Pandemic Period. Indonesian Journal of Teacher Education, 1(2), 61-70.

Hung, M. L., \& Chou, C. (2015). Students' perceptions of instructors' roles in blended and online learning environments: A comparative study. Computers and Education, 81, 315-325. https://doi.org/10.1016/j.compedu.2014.10.022

Irfan, M. (2015). Pemanfaatan Gadget Dalam Pembelajaran Matematika serta Pengaruhnya Pada Mahasiswa yang Mengalami Math-Anxiety Di Universitas Sarjanawiyata Tamansiswa pada Mata Kuliah Persamaan Differensial. SCIENCE TECH: Jurnal Ilmiah Ilmu Pengetahuan Dan Teknologi, 1(1), 68-76.

Kabilan, M. K., \& Khan, M. A. (2012). Assessing pre-service English language teachers' learning using e-portfolios: Benefits, challenges and competencies gained. Computers and Education. https://doi.org/10.1016/j.compedu.2011.11.011

Karasavvidis, I. (2010). Wiki uses in higher education: Exploring barriers to successful implementation. Interactive Learning Environments. https://doi.org/10.1080/10494820.2010.500514

Kemenkes RI. (2020). Pedoman Pencegahan dan Pengendalian Coronavirus Disease (COVID-19). In Direktorat Jenderal Pencegahan dan Pengendalian Penyatkit.

Kim, K.-J., \& Bonk, C. (2006). The Future of Online Teaching and Learning in Higher Education: The Survey Says... EDUCAUSE Quarterly, 29(4), 22-30.

Kim, S., Seo, Y. Bin, \& Jung, E. (2020). Prediction of COVID-19 transmission dynamics using a mathematical model considering behavior changes. Epidemiology and Health, 42. https://doi.org/10.4178/epih.e2020026

Kurt, S. çırak. (2017). A blended learning experience. Elementary Education Online. https://doi.org/10.17051/ilkonline.2017.304740

Laprairie, K. N., \& Hinson, J. M. (2006). When Disaster Strikes, Move Your School Online. Journal of Educational Technology Systems, 35(2), 209-214. https://doi.org/10.2190/d154-xk20-7264-5013

Lin, Y. W., Tseng, C. L., \& Chiang, P. J. (2017). The effect of blended learning in mathematics course. Eurasia Journal of Mathematics, Science and Technology Education, 13(3), 741-770. https://doi.org/10.12973/eurasia.2017.00641a

Mailizar, Almanthari, A., Maulina, S., \& Bruce, S. (2020). Secondary School Mathematics Teachers' Views on E-learning Implementation Barriers during the COVID-19 Pandemic: The Case of Indonesia. EURASIA Journal of Mathematics, Science and Technology Education, 16(7), 1-9. https://doi.org/10.29333/ejmste/8240

Means, B. (2010). Technology and education change: Focus on student learning. Journal of Research on Technology in Education. https://doi.org/10.1080/15391523.2010.10782552

Mulenga, E. M., \& Marbán, J. M. (2020). is-covid-19-the-gateway-for-digital-learning-in- 
mathematics-education. Contemporary Educational Technology, 12(2), ep269. https://doi.org/10.30935/cedtech/7949

Nakamura, Y., Yoshitomi, K., \& Kawazoe, M. (2018). Distance Learning, E-Learning and Blended Learning in Mathematics Education. In Distance Learning, E-Learning and Blended Learning in Mathematics Education. https://doi.org/10.1007/978-3-31990790-1

Ndaïrou, F., Area, I., Nieto, J. J., \& Torres, D. F. M. (2020). Mathematical modeling of COVID-19 transmission dynamics with a case study of Wuhan. In Chaos, Solitons and Fractals. https://doi.org/10.1016/j.chaos.2020.109846

Nuraini, N., Khairudin, K., \& Apri, M. (2020). Modeling Simulation of COVID-19 in Indonesia based on Early Endemic Data. Indonesian Biomathematical Society, 3(1), 1-8. https://doi.org/10.5614/cbms.2020.3.1.1

Özyurt, Ö., Özyurt, H., Baki, A., \& Güven, B. (2013). Integration into mathematics classrooms of an adaptive and intelligent individualized e-learning environment: Implementation and evaluation of UZWEBMAT. Computers in Human Behavior. https://doi.org/10.1016/j.chb.2012.11.013

Peirlinck, M., Linka, K., Sahli Costabal, F., \& Kuhl, E. (2020). Outbreak dynamics of COVID-19 in China and the United States. In Biomechanics and modeling in mechanobiology. https://doi.org/10.1007/s10237-020-01332-5

Pundak, D., Herscovitz, O., \& Shacham, M. (2010). Attitudes of face-to-face and e-learning instructors toward' active learning. European Journal of Open, Distance and ELearning, 13(2).

Rahimi, F., \& Abadi, A. T. B. (2020). Practical Strategies Against the Novel Coronavirus and COVID-19- the Imminent Global Threat. In Archives of Medical Research. https://doi.org/10.1016/j.arcmed.2020.03.005

Resmawan, R., \& Yahya, L. (2020). Sensitivity Analysis of Mathematical Model of Coronavirus Disease (COVID-19) Transmission. Cauchy, 6(2), 91-99. https://doi.org/10.18860/ca.v6i2.9165

Setiawan, A. R. (2020). Scientific Literacy Worksheets for Distance Learning in the Topic of Coronavirus 2019. Reading Academic Article. https://doi.org/10.1016/j.solener.2019.02.027

Setiawan, A. R., \& Ilmiyah, S. (2020). Students' Worksheet for Distance Learning Based on Scientific Literacy in the Topic Coronavirus Disease 2019 (COVID-19). EdArXiv. https://doi.org/10.35542/osf.io/h4632

Smart, K. L., \& Cappel, J. J. (2006). Students' Perceptions of Online Learning: A Comparative Study. Journal of Information Technology Education: Research, 5(1), 201-219. https://doi.org/10.28945/243

Soewono, E. (2020). On the analysis of Covid-19 transmission in Wuhan, Diamond Princess and Jakarta-cluster. Indonesian Biomathematical Society, 3(1), 9-18. https://doi.org/10.5614/cbms.2020.3.1.2

Sözgün, Z., Altinay, Z., Berigel, M., Karal, H., \& Altinay, F. (2018). A practice of e-learning platform in fostering professional development. Quality and Quantity, 52(1), 79-92. https://doi.org/10.1007/s11135-017-0589-1 
Sulisworo, D., Rohmadheny, P. S., Fatimah, N., \& Arif, D. B. (2020). Learning analytics to predict student achievement in online learning during Covid- 19 mitigation. International Journal of Psychosocial Rehabilitation, 24(10), 1844-1861.

Taha, M. H., Abdalla, M. E., Wadi, M., \& Khalafalla, H. (2020). Curriculum delivery in Medical Education during an emergency: A guide based on the responses to the COVID-19 pandemic.

MedEdPublish, 9. https://doi.org/10.15694/mep.2020.000069.1

Tang, S. Y., Xiao, Y. N., Peng, Z. H., \& Shen, H. B. (2020). Prediction modeling with data fusion and prevention strategy analysis for the COVID-19 outbreak. Zhonghua Liu Xing Bing Xue Za Zhi = Zhonghua Liuxingbingxue Zazhi, 41(4), 480-484. https://doi.org/10.3760/cma.j.cn112338-20200216-00107

Tosepu, R., Gunawan, J., Effendy, D. S., Ahmad, L. O. A. I., Lestari, H., Bahar, H., \& Asfian, P. (2020). Correlation between weather and Covid-19 pandemic in Jakarta, Indonesia. Science of the Total Environment. https://doi.org/10.1016/j.scitotenv.2020.138436

Trelease, R. B. (2015). Essential E-Learning and M-Learning Methods for Teaching Anatomy. In Teaching Anatomy. 247-258. https://doi.org/10.1007/978-3-319-089300_28

Van Bruggen, J. (2005). Theory and practice of online learning. British Journal of Educational Technology, 36(1), 111-112. https://doi.org/10.1111/j.14678535.2005.00445_1.x

Vrugt, A., \& Oort, F. J. (2008). Metacognition, achievement goals, study strategies and academic achievement: Pathways to achievement. Metacognition and Learning, 3(2), 123-146. https://doi.org/10.1007/s11409-008-9022-4

Zaharah, Z., \& Kirilova, G. I. (2020). Impact of Corona Virus Outbreak Towards Teaching and Learning Activities in Indonesia. SALAM: Jurnal Sosial Dan Budaya Syar-I, 7(3), 269-282. https://doi.org/10.15408/sjsbs.v7i3.15104 
